Scholedge International Journal of

Management \& Development

ISSN 2394-3378, Vol.04, Issue 12 (2017)

Pg 125-129.

DOI: 10.19085/journal.sijmd041201
Published by: Scholedge Publishing

www.theSCHOLEDGE.org

Email: editorial@thescholedge.org

(C)Publisher

\title{
Globalization minus One: The Emerging Contours of a New Global Economic Order
}

\author{
Prof Dr M S S El Namaki \\ Dean, Victoria University, School of Management, Switzerland. \\ Dean (Retired) Maastricht School of Management, MSM, And The Netherlands.
}

\begin{abstract}
Disruption induces disequilibrium. Today's global economy is the case in point. Powerful sources of disruption are undermining classic premises of global economic equilibrium and, in the process, changing the contours of the World economy. Long cherished globalization premises of free market, open economy, small government, private initiative and deregulation are being challenged. Sources of this challenge are numerous but the most striking is the recent rapid and abrupt USA reclusive and isolationist measures. The United States, the key global economic player, is assuming a protective posture by introducing tariff barriers, annulling international trade agreements, promoting self-serving job creation slogans and hastily recalling industries and services. And all this is uttering threats of crude retaliation. National interest seems to have taken precedence over cross country gains. And others seem to be working on a new framework: globalization minus one. A globalization that is based on new premises and involves the majority of global economic players but one: the United States. This will be the focus of the following article.
\end{abstract}

\section{The Drums of Protection}

Drums of protection are loud. A vast collection of measures taken or announced by the US administration add up to a frontal attack on classic premises of globalization.

\section{- Tariff barriers}

The United States government has very recently introduced a 25\%across the board tariff on imports of steel and $10 \%$ on those of aluminum as a protective measure against foreign competition. The decision was later qualified in order to exempt countries as Canada and Mexico and to open the door for a dilution made dependent on negotiations with others including the EU. The US ultimate goal was to allow the American steel industry to boost capacity to $80 \%$ against the $72 \%$ level of 2017 . National security concerns were the pretext although the US rarely invoked national security to raise trade barriers and did not bring a successful case since the 1980s. The roots may lie in the Commerce Department's view that steel and aluminum imports threaten national security and their recommendation to impose steep tariffs on both. This would be based on Section 232 of the Trade Adjustment Act of 1962, a step that doesn't require congressional approval.(Forbes, March 12, 2018).

\section{- TPP withdrawal}

The Trans-Pacific Partnership or TPP, the multilateral trade agreement that included the United States, Canada, Japan, Australia as well as several countries in Asia and South America, was developed in order to reduce tariffs and enhance trade among the participating countries. Specific US business - friendly arrangements for labor, environment and intellectual property were incorporated in the agreement. It was perceived by President Obama's administration as an economic pillar in its so-called "pivot to Asia". The US government withdrew from the agreement under the pretext that it would reduce employment, increase foreign competition and slows overall economic growth. This withdrawal is regarded by many as an error made without serious analysis or regard for the agreement's very conducive economic and geopolitical role within the Asia and Pacific region. (Foreign Policy, June 22, 2017). 


\section{- NAFTA renegotiations}

NAFTA, the trilateral trade block agreement concluded in Jan 1994 aimed at eliminating barriers to trade and facilitating cross border movement of, goods and services between the United States Canada and Mexico. It is currently subject to threats of renegotiation. The US is suggesting a revision of trade flows in cars, a major item, and the introduction of a sunset clause setting a five year term that should be renegotiated. A clear US goal is to reduce the trade deficit with Canada and Mexico; a questionable focus of a trade policy (CIGI, February 26, 2018).

\section{- WTO challenge}

The United States has been, since the inception of WTO, a model member of the organization almost always adhering to the rules even if that means making politically difficult decisions. The steel and aluminum tariffs imposed on US imports of those products represented a crude departure from this pattern. It represented a blunt flouting of WTO rules and a substitution of the multilateral negotiating pattern of WTO with a free-for-all negotiating process in which trading partners are supposed to bilaterally negotiate an exemption. A flimsy national security pretext was the justification. It all constituted a blunt violation of WTO understanding that trade will be conducted under internationally agreed rules, not ad hoc negotiations. Trump attack on WTO sparks backlash from members - (Financial Times,Dec 10, 2017).

\section{- Crude threats of trade retaliation}

Crude threats followed the announcement of the new US tariff on imports of aluminum and steel. There was a threat to counter any possible EU reaction with a reciprocal barrier against European automakers. This at a time when The United States already imposes a 2.5 percent tariff on the import of foreign cars and a 25 percent tariff on the import of foreign trucks and commercial vans. There was also a promise to escalate the battle by imposing "reciprocal taxes" on other countries, or raise low US tariffs to match those of other countries. Statements as "trade wars are good" and "easy to win" summed up the attitude.EU. (Fortune, Mar 7, 2018)

\section{- Acrimonious cross country exchange}

Trade and industrial policy barriers imposed against countries and political blocks as the EU are done within a conflict ridden framework and an air of trade animosity. China for one put forward the argument that those barriers severely damage the multilateral trading system and disturb the international trading order. And this is at a time when the US administration is seeking transatlantic support in fighting terrorism and increasing defense spending. Some retaliatory measures have been announced by the EU and China with China's statement carrying the same acrimonious spirit by stating that all will be done to protect the country's interest.

\section{- Slanted job creation claims}

Political trade protection arguments in the United States are laced with images of job losses induced by liberal trade policies and practices. Post recent presidential elections media messages seemed to project a picture of enhanced investment and employment induced by the prospective departure from those liberal trade policies. Research supports the notion; however, that bringing back 1950s or even 1980's manufacturing jobs to the U.S.is not realistic given fundamental technology and dexterity shifts. The call for a withdrawal of environmental regulation as a medium for the return of mining jobs, for instance, would not hold ground given the fact that coal industry technology and business model have undergone as radical a change as to render employment patterns of past decades obsolete.

\section{The Preliminary Response}

Trade protection expressed in measures and rhetoric has had repercussions. One of those is a threat of a global trade war where countries try to protect their economic interests by raising the specter of tariff and non-tariff barriers. The following are some of the short term responses.

\section{- China's reciprocity}

The Chinese government argued that the use of national security as the basis for tariffs on steel and aluminum was a smokescreen and the restrictions were economically tinted thus justifying reciprocity under World Trade Organization's rules. China's reciprocity was therefore prompt and wide in terms of 
scope and scale. It first announced plans for reciprocal tariffs on 128 products worth $\$ 3$ Billion of trade. Those included fresh fruit, wine and steel pipes. Then came plans to impose tariffs on a list of key American imports including soya beans, planes, cars, beef and chemicals. Soya beans is a key American export to China and the threat of Chinese tariffs on American soya beans could have far reaching economic and political implications. A $\$ 16.3$ bnworth of civilian aircraft engines and parts were the prime US export to China in 2017. It all adds up to the beginnings of a trade war and a Chinese government message that US economic threats would be matched with equal Chinese force.(The Guardian, April 2018). (China retaliates with new levies on US products(The Guardian, April 4, 2018).

\section{- A TPP minus the United States.}

TPP's eleven remaining members announced, in March 2018, the conclusion of a revised free trade agreement to be re-branded as the "Comprehensive and Progressive Trans-Pacific Partnership" (CPTPP). Member countries contribute 13.5 percent to the global gross domestic product, and aim, ultimately, at setting rules and standards for a trans-Pacific economic community. Canada will, within the new framework, continue to expand and diversify its major regional trade agreements beyond the North American Free Trade Agreement (NAFTA) whose prospects are rather dim. China is not a member of the new agreement preferring to try to build different trade agreements as The Regional Comprehensive Economic Partnership (RCEP) the largest. (Economist, 2018).

\section{- An "African Free Trade Agreement".}

An African Free Trade area has emerged rather suddenly and, to all appearances, as a consequence of the visible turbulence in international trade policies and institutions. Forty-four African countries have concluded a trade agreement paving the way for a cross African liberalized market for goods and services. The African Continental Free Trade Area (AfCFTA) agreement cast in the mold of the European Union's version should lead to the creation of the world's largest free trade area since the World Trade Organization. The agreement commits countries to removing tariffs on 90 percent of goods, with 10 percent of "sensitive items" to be phased in later. Eventually, free movement of people and even a single currency could become part of this free trade area.

\section{- WTO rule breaking.}

The WTO was the crown jewel in the effort to build international economic governance and resort to a flimsy "national security" pretext to impose a forbidding tariff barrier, grossly undermined that. The measure should have normally been scrutinized by judges under the WTO's dispute settlement system, and would have almost certainly been ruled illegal. Imposing tariffs for "national security" by making use of a loophole in WTO law is unconventional and generally avoided practice. If the case goes to WTO court and court concludes that the US broke international law, there is a serious risk that the US administration would ignore the judgment or pull the United States out of the WTO altogether. In that case the credibility and legitimacy of WTO dispute settlement mechanism would be gravely undermined but it will not mean the end of WTO given past US withdrawals from international agreements and the continuity and further growth of those agreements. (The Times, March 16 2018).

\section{- A return to industrial policies.}

There are traces of a search for a new brand of industrial policy in the United States. CEOs of a number of leading corporations including IBM and General Electric have been nudging the United States administration towards a modern day industrial policy that relates education to employment and innovation. The ultimate goal is to move the US economy from a low price consumption driven economy to a quasi - German one where high skill, high pay, high value added and high export are interrelated. This will not be that easy, however, given the high concentration of US industries and issues of monopoly and anti-trust that will arise from any attempt at the ensuing restructuring. They believe is that shift induced by a brand of industrial policies would enhance tax revenues, reduce government debt, introduce new technologies, stimulate exports and, ultimately, ensure a long term trade surplus.(Financial Times, May 2017)

- EU discomfort and reciprocity.

The European Commission promised a response to the threat of the recently imposed American tariff barriers. The sizable number of European jobs that would be put in jeopardy would require a response and 
the commission is contemplating that. The choice is between three measures: taking the case to the World Trade Organization, adding safeguards to protect the European Union against steel diverted from the United States and imposing tariffs on a series of American-made goods. The United States is the world's largest importer of steel, and while low price steel imported from countries like China is the prime source of American concern, the European Union as a whole is the single largest exporter of steel to the United States. The EU is, moreover, worried about an eventual shift in low price steel away from the United States towards the continent and the resulting pressure on European producers. The EU may also impose its own tariff barriers by targeting $\$ 3.5$ billion of American imports including T-shirts, whisky, motorcycles and ladders. (New York Times, March 8, 2018).

\section{What is next? Globalization minus one or Neo-globalization}

A trade war is the likely outcome of the events of the past few months. China, for one, has fired the first reciprocal shot and the EU as well as several other countries seems to follow suit. Where will that take the global trade system and what will be the final outcome?

It is the author's contention that a substitute framework is slowly emerging. A framework that is tackling the anomalies of classic globalization and changing past country, policy and institution roles and patterns."Globalization minus one" or "Neo-globalization" is probably the best way to describe this new framework. A framework with novel contours that could include the following:

\section{- Selective membership}

Though the classic concept of globalization connotes worldwide inclusiveness or a global scale of economic integration, neo-globalization or globalization minus one will divert from that norm. The global scale of economic integration will most likely be replaced by cross country clusters, or groupings built around intra-group common interests. The African Free Trade Association, the CPTPP replacement of the TPP and the Belt and Road Initiative (BRI) are all clusters built around a common purpose. They may expand to include more than the constituting members but to become as global as to include the entire World is, in the short term, unlikely.

\section{- A new conceptual foundation}

Globalization minus one will be based on a high measure of synergy instead of yesterdays ,by now, obsolete competitive advantage. Synergy across countries connotes the creation of a whole that is greater than the simple sum of components and this will become the potent driving force of the new World economy. Cross country synergy congruence could lead to a variety of cross country strategic behavior including industry restructuring, industry concentration, capital market integration, disruptive technology innovation and enhanced capital flows(El Namaki, 2016).

\section{- Different initiative takers}

The role of the United States as initiative taker and leader of the global economy will be challenged. A strong candidate for a leadership is China with followers spreading across a wide spectrum going all the way from South and East Asia satellite States to close alliances as Russia and pragmatic distant followers as Germany. China's economic prowess and pragmatic pro globalization policies will put it in the leadership seat whether it opts for that or not. The United States will, however, continue, for some time, to manipulate the global economy thanks to its dominance of the global capital market and virtual control over global institutions as the World Bank and the IMF.

\section{- Novel drivers.}

Neo-globalization or globalization minus one will be driven by different forces from those that existed during the classic globalization. Investment will be a prime driver and it will focus on infrastructure, disruptive technology and essential economic development. Infrastructure investments in energy, transport, communication, irrigation and water supply raises productivity, reduces costs of market access and increases asset returns. Information and communications technology (ICT) infrastructure is, for instance, found to have positive trade effects for both exporters and importers in Asia (ADB, Dec 2015). Investment in disruptive technology will focus on discontinuity and substitution of what is considered a normal flow of products and services. 


\section{- Different politics}

Political empathy may emerge as a criterion in cross country communication. Political empathy assumes an ability to identify with and understand the perspective, experiences and motivations of another party. Also to comprehend and share attitudes, expressions and views of an opposite number. Demonizing those who hold different views would, within our new framework, be substituted by learning how to see them within a positive framework and express empathy despite the different perspective. This could be exemplified by President Xi's statement "there's "no point" in blaming economic globalization for the world's problems, many of which have nothing to do with global trade"(January 17, 2017, NPR).

\section{Summary and conclusions}

Powerful sources of disruption are undermining classic premises of global economic equilibrium and, in the process, changing the contours of the World economy. Sources of this challenge are numerous but the most striking is the recent rapid and abrupt USA reclusive and isolationist measures. The United States, the key global economic player, is assuming a protective posture by introducing tariff barriers, annulling international trade agreements, promoting self-serving job creation slogans and hastily recalling industries and services. And all this is uttering threats of crude retaliation. National interest seems to have taken precedence over cross country gains. Other countries did and are still in the process of reacting. Signals of a trade war are on the effing. A new TPP was concluded without the United States. China announced and continues to announce a selection of progressively escalating protective barriers of its own. The EU declared displeasure and the intent to introduce reciprocating penalties. A new trade blocks emerged in Africa.

What is next? Others seem to be working on a new framework: globalization minus one. A globalization that is based on new conceptual foundation, new premises and involves the majority of global economic players but one: the United States.

\section{References}

[1] Trump's National Security Tariffs Have Nothing To Do With National Security, Forbes, March 12, 2018.

[2] Environmental regulations account for just 3.5 percent of coal's decline, “,GTM, May 15, 2017

[3] Trump's Five Mistaken Reasons for Withdrawing from TPP, Foreign Policy, Jun 22, 2017.

[4] "NAFTA Renegotiations: What You Need to Know", CIGI, February 26, 2018

[5] "Trump attack on WTO sparks backlash from members", Financial Times, Dec10,2017

[6] "EU: Trump's Car Tariff Threats Are 'Not Based on Facts", Fortune, Mar 7, 2018

[7] China retaliates with new levies on US products, The Guardian, April 4, 2018)

[8] El Namaki, M. S. S. (2016), "From Competitive Advantage to Cross-country Dynamic Synergy", International Journal of Management and Applied Research, Vol. 3, No. 4, pp. 184-191.

[9] Trump A E, China, and Steel Tariffs: The Day the WTO Died, , Council of Foreign Relations, March 9, 2018

[10] US industrial policy, Science and Public Policy, volume 26, number 1, February 1999.

[11] Fostering Investment in Infrastructure Lessons learned from OECD Investment Policy Reviews JANUARY 2015 September 2016

[12] E.U. Pledges to Fight Back on Trump Tariffs as Trade War Looms, New York Times, March 7, 2018

[13] "Trump aims for an industrial policy that works for America", FT, May 7, 2017

[14] ADB Annual Report 2015 - Asian Development Bank

[15] Hogarth R, “Trump will turn trade regulators' fairy dust to ashes if he gets his way”, The Times, March 16 2018.

[16] The Economics of Infrastructure in a Globalized World: Issues, Lessons and Future Challenges1 Timo Henckel Centre for Applied Macroeconomic Analysis, Australian National University Warwick McKibbin Research School of Economics, Australian National University The Brookings Institution Lowy Institute for International Policy June 4, 2010

[17] The Impact of Infrastructure on Trade and Economic Growth in Selected Economies in Asia ADB December 2015.

[18] El Namaki M, "How damaged are investment capital markets today?" Competitiveness Review, Vol. 24 Issue 1, (2014). 